Syntax Literate : Jurnal Ilmiah Indonesia p-ISSN: 2541-0849

e-ISSN : 2548-1398

Vol. 4, No. 9 September 2019

\title{
SUPERVISI KLINIS UNTUK MENINGKATKAN KEMAMPUAN LITERASI DIGITAL GURU SMK NEGERI MANIIS PURWAKARTA
}

\section{Nana Suryana}

Pengawas SMK Kabupaten Purwakarta, Cabang Dinas Wilayah IV, Dinas Pendidikan Propinsi Jawa Barat

Email: nanasuryana.drsmmpd@gmail.com

\begin{abstract}
Abstrak
Kegiatan pembelajaran di sekolah pada saat ini harus mulai menyesuaikan dengan tuntutan era 4.0. Penyesuaian tersebut diantaranya mengimplementasikan kemampuan literasi digital. Tujuannya membuat pembelajaran menjadi lebih menarik minat belajar siswa. Penelitian ini bertujuan untuk: (1) meningkatkan kemampuan guru dalam membuat soal menggunakan aplikasi kahoot dan (2) meningkatkan kemampuan siswa dalam mengerjakan soal yang dibuat guru dengan mengakses soal tersebut melalui browser web menggunakan smartphonenya (android). Metode penelitian yang digunakan adalah penelitian tindakan sekolah, yaitu melaksanakan pembinaan bagi sekelompok guru di suatu sekolah, melalui beberapa siklus, mengunakan sistem spiral refleksi model Kemmis dan Mc Taggart yang dimodifikasi. Strategi/Metode/Teknik Pembinaan yang digunakan pada siklus I dan siklus II adalah model supervisi klinis. Hasil penelitian menunjukkan bahwa setelah dilaksanakan supervisi menggunakan model supervisi klinis, kemampuan guru dalam membuat soal kemudian di share ke seluruh siswa menggunakan aplikasi kahoot menunjukkan adanya peningkatan, dari siklus I ke siklus II. Siklus II mengakhiri pembinaan, dengan indikator skor guru minimal 80.00 sudah diatas $85 \%$.
\end{abstract}

Kata kunci: Supervisi akademik, kemampuan, Literasi digital

\section{Pendahuluan}

Satuan pendidikan harus mulai mengantisipasi revolusi era 4.0 dengan menyesuaikan berbagai perubahan, agar siap melayani para peserta didik yang berasal dari generasi milenial dari sisi literasi dasar dan digital skills (Härtel, 2015). Sejak saat ini guru harus mulai mengembangkan RPP, proses pembelajaran, serta penilaian pembelajaran bersinergi dengan tuntutan era 4.0. Struktur tuntutan era 4.0 yang harus dimiliki oleh lulusan diantaranya: (1) pemecahan masalah yang kompleks; (2) berpikir kritis-kreatif-kerjasama-kolaborasi (kemampuan 4C); (3) manajemen personil; (4) kecerdasan emosional; (5) kontrol kualitas; (6) fleksibilitas kognitif; (7) orientasi layanan; (8) penilaian dan pengambilan keputusan; (9) kemampuan negosiasi, dan 10) 


\section{Nana Suryana}

mendengarkan secara aktif (Forum, 2017). Literasi digital adalah kemampuan menggunakan aplikasi digital dan informasi secara efektif dan efisien dalam berbagai konteks, seperti dunia akademik dan pendidikan, pembelajaran dan pengajaran, penilaian pembelajaran, karier, serta kehidupan sehari-hari (Ahmad, 2018). Struktur tuntutan era 4.0 lainnya adalah: (1) literasi dasar; (2) literasi digital; (3) Literasi digital; dan (4) literasi manusia (Aoun, 2017); (5) literasi budaya-ekonomi-sosial; (6) karir \& kecakapan hidup; (7) kepemimpinan dan tanggung jawab (Trilling \& Fadel, 2009).

Pada dasarnya pekerjaan guru adalah mengkomunikasikan pengalaman kepada siswa (Yusup, 2018). Guru harus memfasilitasi dan mulai mengembangkan kemampuan struktur tuntutan era 4.0 tersebut pada proses pembelajaran yang dilakukannya termasuk proses penilaiannya. Penggunaan aplikasi digital dalam pembelajaran terbukti meningkatkan hasil pembelajaran. Beberapa penelitian yang menunjukkan hal tersebut diantaranya: (Hernani \& Ahmad, 2010) menyimpulkan bahwa keterampilan proses siswa SMP kelas VII meningkat setelah menggunakan pembelajaran berbasis Literasi digital; (2) (Bella, 2018) menyimpulkan bahwa penerapan literasi digital dan teknologi memiliki pengaruh yang signifikan terhadap peningkatan pembelajaran siswa SMP Negeri 6 Banda Aceh, dan (3) (Husain, 2014) menyimpulkan bahwa penggunaan teknologi informasi dan teknologi sebagai media pembelajaran meningkatkan motivasi belajar siswa SMP, dan (4) (Haristy, Enawaty, \& Lestari, 2013) menyimpulkan terdapat perbedaan hasil belajar antara siswa yang belajar menggunakan pembelajaran berbasis literasi dibanding dan yang belajar menggunakan pembelajaran konvensional.

Salah satu upaya untuk meningkatkan kualitas proses dan hasil pembelajaran siswa, diantaranya dengan meningkatkan kemampuan guru dalam memanfaatkan aplikasi digital dalam proses pembelajaran dan penilaian hasil belajar, salah satunya kahoot (M.T, 2011). Kahoot adalah salah satu aplikasi digital yang dapat digunakan guru pada saat melaksanakan pembelajaran dan penilaian. Guru dapat menggunakan aplikasi kahoot untuk membuat soal atau tes.

Soal tersebut di share ke seluruh siswa untuk dikerjakan dengan mengaksesnya melalui browser web menggunakan smartphone. Untuk mencapai tujuan tersebut perlu adanya pembinaan yang dilakukan oleh pengawas sekolah dengan menerapkan metode atau model supervisi yang bermutu (Nomor, 2008) (Sujana, 2011) (Gebhard, 1990) (Wilson, 2006) (Heble, 2006) (Mehrunnisa, 2000) (Mosavi, 2014) dan (Berk, 1995). 
Hal inilah yang mendorong peneliti telah melaksanakan penelitian tindakan sekolah dengan menerapkan model supervisi klinis untuk meningkatkan kemampuan guru SMK Negeri Maniis Purwakarta dalam membuat soal menggunakan aplikasi kahoot kemudian menyebarkan tautan soal tersebut ke seluruh siswa melalui media sosial internet.

\section{Metode Penelitian}

Metode penelitian yang digunakan adalah Penelitian Tindakan Sekolah yaitu melaksanakan pembinaan bagi sekelompok guru di SMK Negeri Maniis Purwakarta, melalui beberapa siklus, mengunakan sistem spiral refleksi model Kemmis dan Mc Taggart yang dimodifikasi (Sukidin, 2002) (Sumarno, 2005) dan (Wiriaatmadja, 1999), dengan tahapan mulai dari merencanakan pembinaan setiap siklus, pelaksanan pembinaan setiap siklus, observasi pelaksanaan dan refleksi pembinaan setiap siklus, yang dilakukan dari siklus I sampai siklus II dan seterusnya sampai diperoleh rekomendasi kemampuan guru pada siklus terakhir tuntas. Indikator ketuntasan apabila telah mencapai $85 \%$ subjek daya serapnya $\geq 80 \%$ (Depdikbud, 1994) (Sudjana, 2001) (Arikunto, 2010).

Untuk memperoleh data yang diharapkan, maka dalam penelitian ini digunakan instrumen sebagai berikut: (1) rencana pelaksanaan pembinaan; (2) pedoman observasi aktivitas guru; (3) daftar chek aktivitas guru; (4) Instrumen evaluasi guru dalam membuat dan menyebarkan soal menggunakan aplikasi kahoot; (5) format observasi pembinaan; (6) format diskusi balikan; dan (7) Daftar hadir guru.

Data yang telah diperoleh pada setiap tahapan siklus diolah dan dinalisis melalui enam tahap, yaitu: (1) kategori data, (2) interpretasi data, (3) validitas data, (4) pelaksanaan siklus, (5) evaluasi, dan (6) analisis dan refleksi.

\section{Hasil Penelitian dan Pembahasan}

\section{Hasil}

Selama penelitian, observer (rekan pengawas) mengamati dan mengobservasi pelaksanaan pembinaan yang dilakukan peneliti menggunakan pencatatan lapangan (lembar observasi) dan lembar diskusi balikan. 
Diskusi balikan tujuannya untuk mendapatkan informasi mengenai kekurangan-kekurangan penerapan model supervisi klinis. Kekurangan tersebut menjadi dasar untuk memperbaiki dan menyempurnakan pelaksanaan siklus selanjutnya. Perubahan yang terjadi tidak hanya dari cara hasil pembinaan, tetapi dilihat juga dilihat dari proses pembinaannya, yaitu aktivitas guru. Aktivitas guru dan perolehan skor guru, selama pembinaan dari siklus I sampai siklus II telah mengalami perbaikan dan peningkatan.

Hasil observasi terhadap pelaksanaan pembinaan menunjukkan bahwa kemampuan guru pada siklus II lebih baik dan tinggi dibanding siklus I, dengan demikian kegiatan pembinaan pada siklus II berupa penerapan model supervisi klinis telah berhasil dengan baik meningkatkan kemampuan guru dalam membuat dan menyebarkan soal menggunakan aplikasi kahoot.

Proses pembinaan pada siklus II telah memperlihatkan adanya peningkatan aktivitas guru dibanding pada siklus I, mulai dari mengisi identitas menu, mengisi identitas quiz, memasukkan butir quiz, melengkapi isian quiz dan menyebarkan tautan quiz ke seluruh siswa melalui media sosial internet. Aktifitas guru selama pembinaan pada siklus II dapat dilihat dari Tabel 1

Tabel 1

Aktivitas Guru Selama Pembinaan dari Siklus I-siklus II

\begin{tabular}{|c|c|c|c|c|c|c|c|c|c|c|}
\hline \multirow{3}{*}{$\begin{array}{c}\text { Jumlah } \\
\text { Guru \& } \\
\text { Prosentase }\end{array}$} & \multicolumn{10}{|c|}{ Aktivitas Guru Selama Pembinaan pada Siklus I - II } \\
\hline & \multicolumn{2}{|c|}{$\begin{array}{c}\text { Terampil } \\
\text { mengisi } \\
\text { identitas menu }\end{array}$} & \multicolumn{2}{|c|}{$\begin{array}{c}\text { Terampil } \\
\text { mengisi } \\
\text { identitas quiz }\end{array}$} & \multicolumn{2}{|c|}{$\begin{array}{l}\text { Terampil } \\
\text { memasukkan } \\
\text { butir quiz }\end{array}$} & \multicolumn{2}{|c|}{$\begin{array}{c}\text { Terampil } \\
\text { melengkapi } \\
\text { isian quiz }\end{array}$} & \multicolumn{2}{|c|}{$\begin{array}{c}\text { Terampil } \\
\text { menyebarkan } \\
\text { tautan quiz ke } \\
\text { seluruh } \\
\text { siswa melalui } \\
\text { media } \\
\text { sosial internet }\end{array}$} \\
\hline & I & II & I & II & $\mathrm{I}$ & II & I & II & $\mathrm{I}$ & II \\
\hline $\begin{array}{c}\text { Jumlah } \\
\text { Guru }\end{array}$ & 14 & 19 & 13 & 17 & 12 & 16 & 13 & 17 & 14 & 18 \\
\hline Prosentase & 66.67 & 90.48 & 61.90 & 80.95 & 57.14 & 76.19 & 61.90 & 80.95 & 66.67 & 85.71 \\
\hline
\end{tabular}

Data pada Tabel 1 menunjukkan bahwa kemampuan guru dalam mengisi identitas menu dengan terampil dari siklus I sampai siklus II mengalami peningkatan. Pada siklus I guru yang benar-benar terampil berjumlah 14 orang (66.67\%), dan pada siklus II berjumlah 19 orang (90.48\%). 
Kemampuan guru dalam mengisi identitas quiz dengan terampil dari siklus I sampai siklus II mengalami peningkatan. Pada siklus I guru yang benar-benar terampil berjumlah 13 orang $(61.90 \%)$, dan pada siklus II berjumlah 17 orang $(80.95 \%)$.

Berdasarkan data pada Tabel 1 kemampuan guru dalam melakukan memasukkan butir quiz dengan terampil dari siklus I sampai siklus II mengalami peningkatan. Pada siklus I guru yang benar-benar terampil berjumlah 12 orang (57.14\%), dan pada siklus II berjumlah 16 orang (76.19\%).

Kemampuan guru dalam melengkapi isian quiz dengan terampil dari siklus I sampai siklus II mengalami peningkatan. Pada siklus I guru yang benar-benar terampil berjumlah 13 orang $(61.90 \%)$, dan pada siklus II berjumlah 17 orang $(80.95 \%)$.

Berdasarkan data pada Tabel 1 kemampuan guru dalam menyebarkan tautan quiz ke seluruh siswa melalui media sosial internet dengan terampil dari siklus I sampai siklus II mengalami peningkatan. Pada siklus I guru yang benar-benar terampil berjumlah 14 orang $(66.67 \%)$, dan pada siklus II berjumlah 18 orang $(85.71 \%)$.

Berdasarkan hasil skor guru dalam membuat dan menyebarkan soal menggunakan aplikasi kahoot selama pembinaan, menunjukkan adanya peningkatan skor guru pada siklus II dibanding siklus I. Peningkatan skor guru dapat dilihat pada Tabel 2 berikut:

Tabel 2.

Skor Guru dari Siklus I-II

\begin{tabular}{cccc}
\hline \multirow{2}{*}{ No } & \multirow{2}{*}{ Kode Guru } & \multicolumn{2}{c}{ Nilai } \\
\cline { 2 - 4 } & & Siklus I & Siklus II \\
\hline 1 & $\mathrm{AA}$ & 70 & 80 \\
\hline 2 & $\mathrm{AB}$ & 60 & 70 \\
\hline 3 & $\mathrm{AC}$ & 80 & 90 \\
\hline 4 & $\mathrm{AD}$ & 70 & 80 \\
\hline 5 & $\mathrm{AE}$ & 80 & 90 \\
\hline 6 & $\mathrm{AF}$ & 60 & 70 \\
\hline 7 & $\mathrm{AG}$ & 70 & 80 \\
\hline 8 & $\mathrm{AH}$ & 70 & 80 \\
\hline 9 & $\mathrm{AI}$ & 80 & 90 \\
\hline 10 & $\mathrm{AJ}$ & 70 & 80 \\
\hline 11 & $\mathrm{AK}$ & 80 & 90 \\
\hline
\end{tabular}




\begin{tabular}{|c|c|c|c|}
\hline \multirow{2}{*}{ No } & \multirow{2}{*}{ Kode Guru } & \multicolumn{2}{|c|}{ Nilai } \\
\hline & & Siklus I & Siklus II \\
\hline 12 & $\mathrm{AL}$ & 60 & 70 \\
\hline 13 & $\mathrm{AM}$ & 70 & 80 \\
\hline 14 & AN & 70 & 80 \\
\hline 21 & $\mathrm{AO}$ & 80 & 90 \\
\hline 16 & AP & 80 & 90 \\
\hline 17 & AQ & 70 & 80 \\
\hline 18 & $\mathrm{AR}$ & 80 & 90 \\
\hline 19 & AS & 70 & 80 \\
\hline 20 & $\mathrm{AT}$ & 70 & 80 \\
\hline 21 & $\mathrm{AU}$ & 70 & 80 \\
\hline \multicolumn{2}{|c|}{ Rata-rata } & 71.90 & 81.90 \\
\hline \multicolumn{2}{|c|}{ DSK } & $57.14 \%$ & $85.71 \%$ \\
\hline
\end{tabular}

Berdasarkan data pada Tabel 2, dapat dijelaskan:

a) Pada Siklus I, skor tertinggi adalah 80.00 , terendah 60.00 dan rata-ratanya adalah 71.90 serta jumlah guru yang mengalami ketuntasan belajarnya sebanyak 12 orang $(57.14 \%)$.

b) Pada Siklus II, nilai rata-rata harian tertinggi adalah 90.00, terendah 70.00 dan rata-ratanya adalah 81.90 serta jumlah guru yang mengalami ketuntasan belajarnya sebanyak 18 orang $(85.71 \%)$.

\section{Pembahasan}

Hasil observasi proses pembinaan dari siklus I sampai Siklus II, menggambarkan bahwa aktivitas guru menunjukan pola yang aktif, serta antusias mengikuti setiap sesi pembinaan.

Hampir semua guru berperan aktif membuat dan menyebarkan soal menggunakan aplikasi kahoot, mulai dari mengisi identitas menu, mengisi identitas quiz, memasukkan butir soal, melengkapi isian quiz dan menyebarkan tautan quiz ke seluruh siswa melalui media sosial internet. Walaupun pada awalnya banyak yang belum terampil tetapi pada siklus II sudah menunjukkan kemajuan yang sangat pesat.

Hasil observasi proses pembinaan dari siklus I sampai siklus II, menggambarkan bahwa skor guru menunjukan adanya peningkatan. Data pada Tabel 1 menunjukkan bahwa penerapan model supervisi klinis meningkatkan keterampilan guru dalam membuat dan menyebarkan soal menggunakan aplikasi 
kahoot. Hal ini terlihat dari adanya peningkatan prosentase nilai guru pada siklus I dengan siklus II. Kondisi tersebut menunjukkan bahwa guru sudah mulai memahami cara membuat dan menyebarkan soal menggunakan aplikasi kahoot. Peningkatan tersebut terjadi karena pada siklus II guru sudah memiliki pengalaman dan pengetahuan tentang kekurangan-kekurangan pada siklus I dari hasil supervisi klinis dan penilaian sendiri melalui learning community. Dengan demikian penggunaan model supervisi klinis meningkatkan kemampuan guru dalam membuat dan menyebarkan soal menggunakan aplikasi digital yaitu aplikasi Kahoot. Peningkatan terjadi karena adanya guru sudah mahir mendiagnosis kekurangan-kekurangan pada siklus sebelumnya, melalui proses penilaian sendiri dan sejawat melalui hubungan yang bersifat kolegial, dengan cara kolaborasi yang harmonis, melalui learning community dibawah bimbingan dan arahan pengawas sekolah (Dewey, 1938; Duch, 1996; dan Cascio, 1991; Castetter, 2004; Freeman, 1995; Elizabeth \& Wilson, 2006; Geeta, 2006; Mehrunnisa, 2000; Mosavi, 2014; dan Berk, 1995). Selain itu peningkatan menunjukkan bahwa setiap guru telah melaksanakan dan mengikuti tahap-tahap jalannya kegiatan pembinaan, serta menunjukan bahwa hampir semua guru berperan aktif mengikuti setiap sesi pembinaan yang dilakukan oleh peneliti. Sehingga pada saat dilaksanakan pengukuran kemampuan dan keterampilan guru dalam membuat dan menyebarkan soal menggunakan aplikasi Kahoot, pada siklus II, sudah $85.71 \%$ guru memperoleh skor 80.00 ke atas. Selain itu proses bimbingan dan arahan selama proses pembinaan yang dilakukan sudah diupayakan intensif. Sehingga guru tidak mengalami kesulitan dalam melaksanakan proses pembinaan dalam membuat dan menyebarkan soal menggunakan aplikasi kahoot.

\section{Kesimpulan}

1) Penggunaan model supervisi klinis meningkatkan kemampuan guru dalam membuat dan menyebarkan soal menggunakan aplikasi digital yaitu aplikasi Kahoot.

2) Model supervisi klinis meningkatkan kemampuan guru dalam mendiagnosis kekurangan-kekurangan pada siklus I, melalui proses penilaian sendiri dan sejawat melalui hubungan yang bersifat kolegial, dengan cara kolaborasi yang harmonis, 


\section{Nana Suryana}

melalui learning community dibawah bimbingan dan arahan pengawas sekolah. Pelaksanaan siklus II merupakan hasil perbaikan dari pelaksanaan siklus I. 


\section{BLIBIOGRAFI}

Ahmad, I. (2018). Proses pembelajaran digital dalam era revolusi industri 4.0. Direktur Jenderal Pembelajaran Dan Kemahasiswaan. Kemenristek Dikti.

Arikunto, S. (2010). Prosedur penelitian. Jakarta: rineka cipta.

Bella, E. (2018). Pengaruh Penerapan Literasi Digital \& Teknologi terhadap Peningkatan Pembelajaran Siswa di SMP Negeri 6 Banda Aceh. Skripsi. UIN ArRantry Darussalam-Banda Aceh.

Berk, J. B. S. (1995). Total Quality Management: Implementing Continuous Improvement. Kuala Lumpur: S. Abdul Madjeed \& Co.

Depdikbud, R. I. (1994). Pedoman Pembinaan Profesional Pendidik Sekolah Dasar. Jakarta: Direktorat Jenderal Pendidikan Dasar dan Menengah.

Forum, W. E. (2017). Realizing Human Potential in the Fourth Industrial Revolution: An Agenda for Leaders to Shape the Future of Education, Gender and Work.m.

Gebhard, J. G. (1990). Models of Supervision: Choices in J. Richards and D. Nunan (Eds) Second Language Teacher Education. Cambridge: Cambridge University Press.

Haristy, D. R., Enawaty, E., \& Lestari, I. (2013). Pembelajaran Berbasis Literasi Sains pada Materi Larutan Elektrolit dan Non Elektrolit di SMA Negeri 1 Pontianak. Jurnal Pendidikan Dan Pembelajaran, 2(12).

Härtel, M. (2015). No Title. Retrieved from www.unevoc.unesco.org/up/ICT_TVET_UNEVOC_Haertel_ELA2015.pdf

Heble, G. (2006). A model of expert instructional supervision: A descriptive cross case study. Wilmington College (Delaware).

Hernani \& Ahmad, M. (2010). Pengaruh Pembelajaran Berbasis Literasi Sains dan Teknologi terhadap Keterampilan Proses SAINS siswa SMP. Jurnal Pendidikan Matematika Dan Sains Edisi I Tahun XV.

Husain, C. (2014). Pemanfaatan teknologi informasi dan komunikasi dalam pembelajaran di SMA Muhammadiyah Tarakan. Jurnal Kebijakan Dan Pengembangan Pendidikan, 2(2).

M.T, M. (2011). Edmodo: Social Network Berbasis Sekolah. Retrieved from Available website: http://p4tkmatematika.org/2011/12/edmodo-social-network-berbasissekolah

Mehrunnisa, A. A. (2000). Supervision for teacher development, International of educational development. pergamon. 
Nana Suryana

Mosavi, F. (2014). Present a Conceptual Framework of Supervisory System for Teacher. Journal of Educational and Management Studies, 4(4), 738-744.

Nomor, U.-U. R. I. (2008). Metode dan Teknik Supervisi. Ditendik-Dirjen PMPTK. Jakarta.

Sudjana, N. (2001). Tuntunan penyusunan karya ilmiah. Bandung: Sinar Baru Algensindo.

Sujana, D. (2011). Buku Kerja Pengawas. Jakarta: Pusat Pengembangan Tenaga Kependidikan, Badan PSDM dan PMP, Kementrian Pendidikan Nasional.

Sukidin, D. (2002). Manajemen Penelitian Tindakan Kelas. Jakarta: Insan Cendekia.

Sumarno, U. (2005). Penelitian Siklus. Makalah. UPI. Tidak Diterbitkan.

Trilling, B., \& Fadel, C. (2009). 21st Century Skills.: Learning for Life in Our Times. John Wiley \& Sons.

Wilson, E. K. (2006). The impact of an alternative model of student teacher supervision: Views of the participants. Teaching and Teacher Education, 22(1), 22-31.

Wiriaatmadja. (1999). Penelitian Tindakan dalam Bentuk Siklus Sebagai Upaya Meningkatkan Kemahiran Profesional Dosen di Perguruan Tinggi. Jurnal Mimbar Penelitian, No 30/Juli.

Yusup. (2018). Upaya Meningkatkan Kemampuan Guru Dalam Penggunaan Media Komputer Melalui Pelatihan Di SMP N 2 Kapetakan. Syntax Literate; Jurnal Ilmiah Indonesia, 3, No 9 Se, 139. 